\title{
THE GENETICS OF SOMATIC MAMMALIAN CELLS
}

\author{
THEODORE T. PUCK \\ Eleanor Roosevelt Institute for Cancer Research \\ 4200 East Ninth Avenue \\ Denver, Colorado 80220
}

SUMMARY

Somatic cell genetics is an application of the concepts and techniques of microbial genetics to somatic cells of higher organisms. Applied to mammalian systems, it has made possible clone isolation, quantitation of cell reproduction, establishment of cell survival curves, somatic chromosome analysis, single gene mutations, measurement of mutagenic action, cell hybridization with and without chromosome loss, dominance determination, complementation analysis, synteny determination, and a variety of applications to medicine and to research on genetic control mechanisms.

\section{INTRODUCTION}

Classical genetics is a science which analyzes the results of matings of the germ cells of selected, multicellular individuals and explains the distribution of various characteristics among the progeny of such matings. Microbial genetics is another kind of genetics which developed as a new discipline during the first half of this century. In this approach singlecelled microorganisms, capable of multiplying asexually are grown into colonies, called clones, which represent the most uniform possible biological population. Mutant clones can be recognized and selected, and their properties studied. When, to this kind of genetic study, were added the possibility of mating procedures on the one hand and molecular analysis of gene structure and action on the other, a new science was born called molecular biology, which has revolutionized biological science. Now a third kind of genetics called somatic cell genetics has been developed and applied to animals generally and to man in particular. It has greatly accelerated the growth of under- 
standing of mammalian genetics and genetic biochemistry. Somatic cell genețics resulted from application of the methodology of microbial genetics to the somatic cells of multicellular organisms. It was conceived as a means of speeding up genetic analysis in forms like man where normal reproduction is slow, and where the particular matings which would be most illuminating scientifically are often difficult or impossible to perform. It has accomplished these objectives, and also has made possible new kinds of genetic experimental operations (1).

The principle underlying somatic cell genetics involves the use of biopsies of somatic cells. These cells are cultivated in vitro as microorganisms and their genetic processes are studied by the methods of microbial genetics. In this way it becomes possible to bypass the slow and complex normal mammalian reproductive process. Thus, much more rapid generation times are secured since one is studying the reproduction of individual cells instead of the whole organism. Moreover, the behavior of a wide variety of genomes can be studied in vitro at the will of the experimenter. Finally, the ability to control the environmental conditions afforded by the in vitro situation affords a weighty advantage to this approach. The present brief review summarizes work from our laboratories which has been carried on during the last 18 years and which was made possible by the combined contributions of a large group of dedicated colleagues.* While occasional mention is also made of work from other laboratories, this paper is by no means a comprehensive or representative assessment of the many important developments in this field that have occurred in laboratories in various parts of the world.

\section{CULTURE CONDITIONS}

The first logical step in this approach requires development of a means for reliable establishment of cultures of cells from any person or experimental animal (Fig. 1). This was accomplished by modifying the traditional methods of tissue culture so as to provide better control of the cellular environment with respect to $\mathrm{CO}_{2}$ concentration, the relative humidity which determines the osmolarity of the dissolved solutes, and the temperature. Electronically controlled incubators were developed for this purpose (2).

*The studies performed in these laboratories have formed a collaborative effort which has involved R. Christianson, P. Marcus, J.H.: Tjio, A. Robinson, S. Cieciura, H. Fisher, L. Tolmach, S. Levine, G. Sato, C. Waldren, P. Wuthier, C. Jones, W. Goad, J. Steffan, H.H. Lee, D. O'Brien, M. Oda, M. Yamada, J. Engelberg, R. Ham, R. Gamewell, J.C. Daniel, F.T. Kao, H. Hill, L. Chasin, P. Rao, R. Johnson, A. Tourian, J. Goddard, D. Patterson, M. Fulwyler, D. Cox, F.F. Yew, A. Morrisey, C. Kahn, A. Hsie, T. Stamato, C. Walker, L. Wenger, B. Storrie, A.J. Kauvar, and the author. 
Modifications of standard tissue culture nutritional media and procedures were devised (4) which many scientists and particularly Harry Eagle and his group had pioneered (3), which permitted routine success in production of viable cultures in vitro from biopsies (4). These media modifications also maximized the growth rate of the resulting cells, and made possible continuous cultivation of cells with normal karyotype for reasonably long periods (5). A method for routine and quantita-

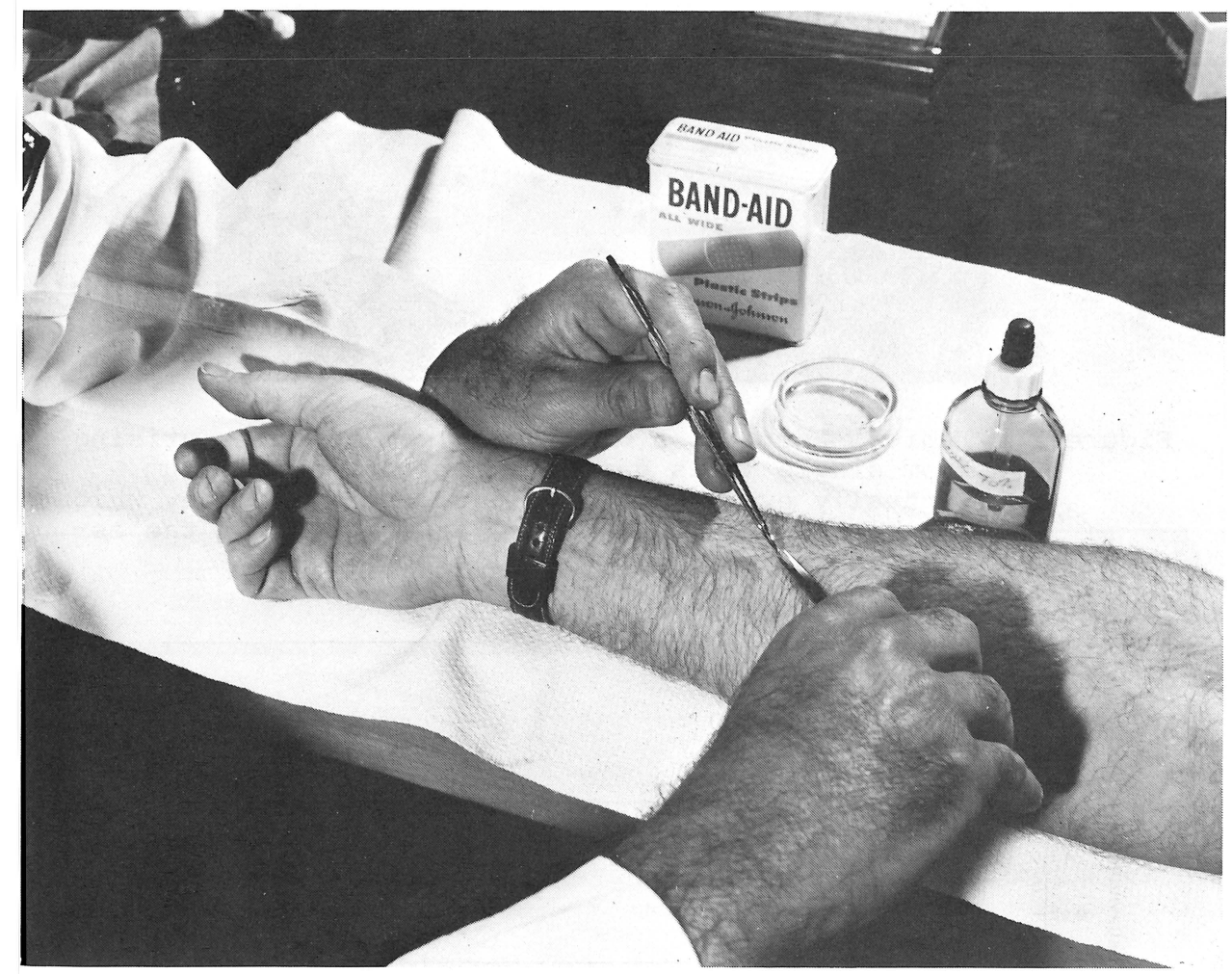

Figure 1. Demonstration of the process of taking a biopsy of skin from a human subject. The amount of tissue required for reliable establishment of a long-term culture is approximately 1 milligram.

tive growth of single cells was developed so that virtually every cell deposited on a glass surface developed into an isolated colony (Fig. 2). The percentage of cells deposited in such a dish or plate which grow into colonies (i.e. the plating efficiency) could then be determined routinely under any desired conditions so that quantitative survival curves for effects of physical, chemical, and biological agents on cell reproduction could be established. Since each colony is a clone, 


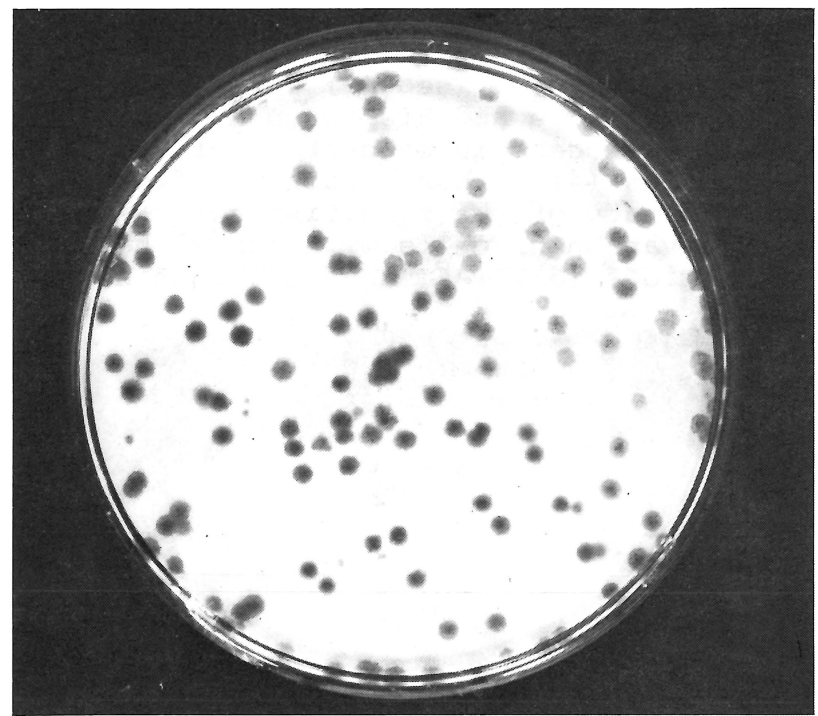

Figure 2. Typical Petri dish displaying the colonies arising from single cells deposited in nutrient medium. Virtually every single cell produces a colony which can be recognized, counted, and picked for the establishment of a new clonal stock.

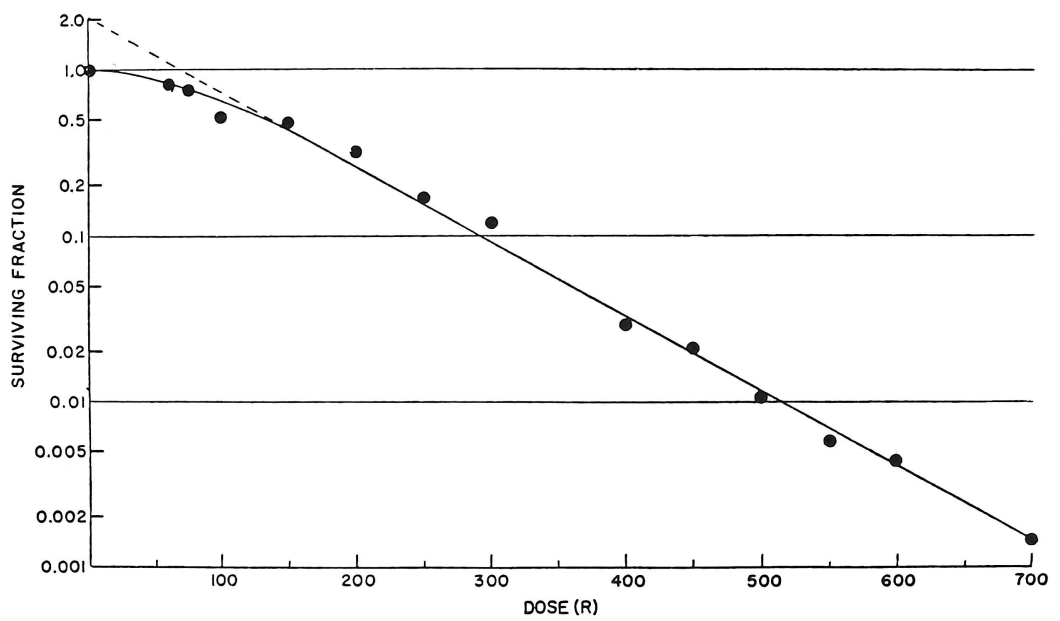

Figure 3: $x$-ray survival curve for a typical human cell grown in culture.

mutant clones could be recognized, selected, and made the basis of new stocks with markers usable in genetic experiments (6). Single cell survival curves could now be accurately and conveniently constructed (Fig. 3). Such curves have permitted analysis of mechanisms underlying killing of mammalian cells by various agents. 
GENETICS OF MAMMALIAN CELLS

51

CHROMOSOME ANALYSIS

Establishment of the Human Chromosome Study group with representatives from laboratories from several countries led to a system of identification and classification of the human chromosomes which was quickly followed by the establishment of cytogenetics as a new branch of medicine $(7,8)$. It was gratifying to see how quickly the basic laboratory procedures became applied routinely to important medical problems. The identification of disease conditions as due to specific chromosomal abhormalities was first initiated by LeJEUNE and his coworkers in

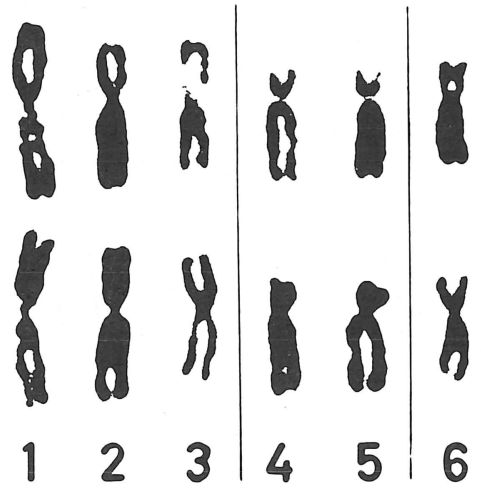

$x$
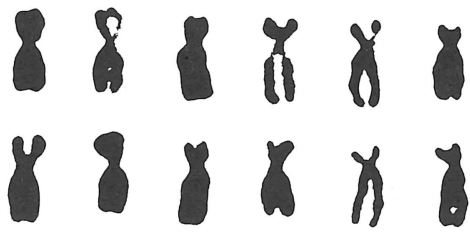

$\begin{array}{llllll}7 & 8 & 9 & 10 & 11 & 12\end{array}$

6

\& 13

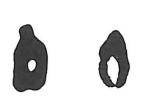

( 9

1415
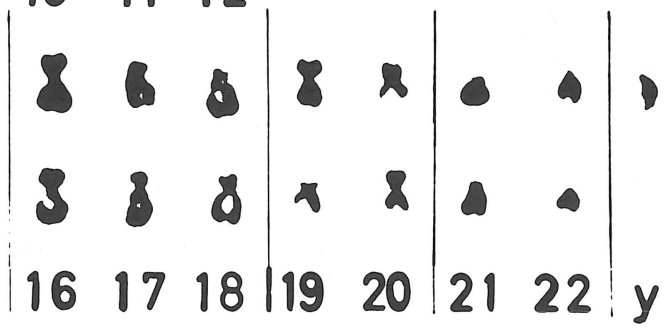

Figure 4. The human male karyotype according to the Denver System of Classification.

Paris (9), and was followed by a wave of exciting discoveries from many other laboratories. It was demonstrated that approximately a half percent of all human live births are attended by chromosomal anomalies which can produce the most deep-seated 
disease conditions. Recently, the introduction of chromosomebanding techniques has revolutionized chromosomal analysis and promises many new developments of importance in medicine (10). In addition to the immediate clinical implications of these discoveries, new fields for study were opened up in the epidemiology of chromosomal diseases, and in exploration of the significance of such chromosomal anomalies for the understanding of mechanisms involving human embryological and post-natal development. Such studies, now going on in centers throughout the world, promise important illumination of both normal and aberrant developmental processes.

\section{MUTAGENES I S}

Attention was next turned to genetic analysis at the single gene level. The first problem involved the necessity for obtaining single gene mutations which could serve as effective

DEFICIENT CELL

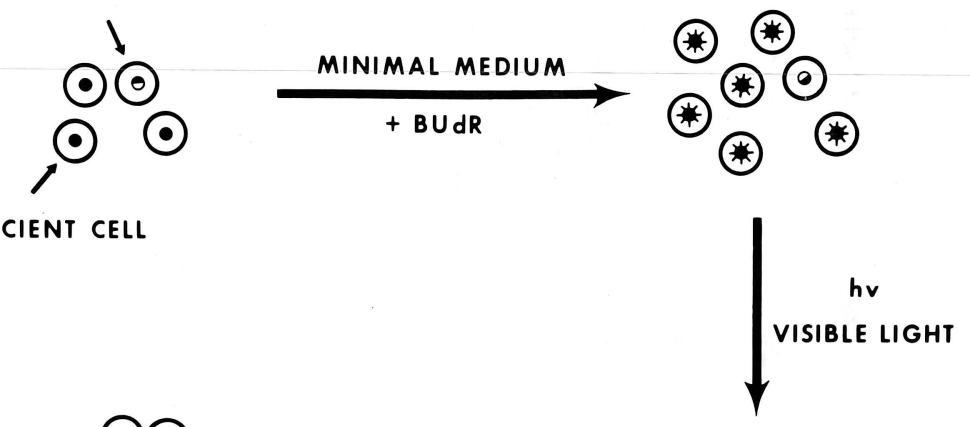

SUFFICIENT CELL

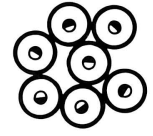

ENRICHED MEDIUM

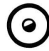

COLONY

Figure 5. Demonstration of the operations involved in the BUdRnear visible light technique for isolation of auxotrophic mutants.

genetic markers. Because mammalian cells often exhibit physiological resistance to drugs and other agents which can mimic true mutations, our group decided to search for auxotrophic mutants in which the need for a specific metabolite for growth might serve as a more reliable marker than drug- or virus-resistance. A minimal medium was developed in which our standard Chinese hamster ovary cell could grow with approximately $100 \%$ plating efficiency, but for which the plating efficiency drops to zero if any major component of the medium is omitted. The next problem was to devise a means for isolating auxotrophic mutants which were incapable of growth unless the basal medium was supplemented with specific metabolites (11, 12). The method developed is analogous to the penicillin method for isola- 
tion of auxotrophic mutants in bacteria. It arranges conditions so that the cells competent to multiply in the deficient medium are killed by a process which does not affect the non-multiplying auxotrophic mutants. Thus, the great majority of the wildtype cells can be selectively killed. Thereafter the medium is changed to a non-toxic form, metabolic enrichments are added and the previously dormant auxotrophic cells now initiate multiplication and form colonies which can be isolated and their new nutritional requirements determined.

The method (known as the BUdR-near visible light technique) involves placing a mutagenized culture in basal medium along with bromodeoxyuridine (BUdR) (Fig. 5). This analog of pyrimidine is incorporated into the DNA of only those cells which are capable of multiplication in the basal medium. Thus, after a short starvation period to deplete cellular reservoirs, BUdR
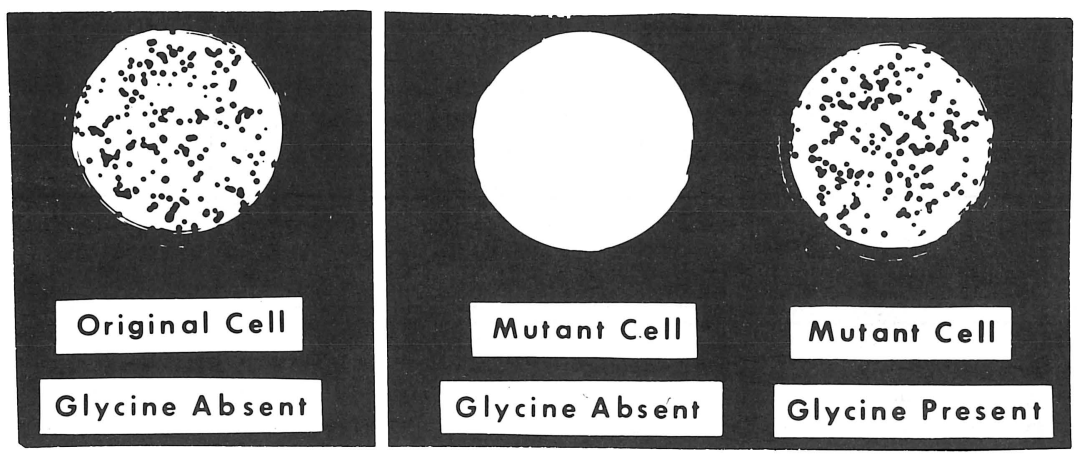

Figure 6. Demonstration that the glycine-requiring mutant differs from the wild-type in that it produces no colonies whatever in the absence of glycine, but produces colonies with virtually $100 \%$ efficiency if glycine is added to the medium.

becomes incorporated into the DNA of the wild-type cells only, while that of the auxotrophs remains in the native state. Thereafter, the entire cell population is subjected to the action of near-visible light. Those cells which have incorporated BUdR into their DNA undergo a shift of their $2600 \AA$ absorption band toward the visible region so that these cells selectively absorb visible and near-visible light and are destroyed. The auxotrophic mutants are not affected. The cell population is then plated in enriched medium, the colonies which develop are picked, and their nutritional requirements are defined. Colonies which are found to have stable new nutritional requirements are selected and cultivated as new mutated stocks (Fig.6).

Cell populations which have not been previously exposed to mutagens fail to produce mutants when subjected to the BUdRvisible light technique. Cells exposed to mutagens, however, yield large numbers of mutants when subjected to this procedure. The procedure has permitted isolation of auxotrophic mutants requiring amino acids, purines, pyrimidines, sugars, folinic acid 
and other substances (13). The collection of mutants so obtained has proved to be useful in many kinds of genetic and genetic-biochemical studies.

\section{HYBR I DI ZAT I ON}

Somatic cell genetics was enormously advanced by the discovery of cell hybridization, a discovery which is due to the work of the laboratories of DrS. OKADA, BARSKI, EPHRUSSI, and HARRIS (14). By means of this process, it became possible to produce matings between somatic mammalian cells in vitro. Thus, many new kinds of genetic analyses were made available.

\section{ALLELISM TESTS}

When cells of animals of the same species are fused with the aid of irradiated Sendai virus, the resulting hybrids main-

Table 1. Summary of the complementation behavior found in analysis of the adenine-requiring mutants of the CHO-KI cell so far obtained.

\begin{tabular}{lcccccccc}
\hline & $\begin{array}{c}\text { ade } \\
\text { A }\end{array}$ & $\begin{array}{c}\text { ade } \\
\text { B }\end{array}$ & $\begin{array}{c}\text { ade } \\
\text { C }\end{array}$ & $\begin{array}{c}\text { ade } \\
\text { D }\end{array}$ & $\begin{array}{c}\text { ade } \\
\text { E }\end{array}$ & $\begin{array}{c}\text { ade } \\
\text { F }\end{array}$ & AT* & GAT** \\
\hline ade A & - & & & & & & \\
ade B & + & - & & & & & \\
ade C & + & + & - & & & & \\
ade D & + & + & + & - & & & \\
ade E & + & + & + & + & - & & \\
ade F & + & + & + & + & + & - & + \\
AT & + & + & + & + & + & + & + \\
GAT & + & + & + & + & + & + & + \\
\hline
\end{tabular}

$A+\operatorname{sign}$ means 30 to 100 colonies were obtained as. a result of plating $10^{4}$ cells of a fusion mixture containing equal numbers of each cell pair employed. A - sign indicates no colonies were obtained. The data indicate that all of the mutations are recessive.

${ }^{*} \mathrm{AT}=$ a mutant requiring both adenine and thymidine for growth.

**GAT $=$ a mutant requiring glycine, adenine, and thymidine for growth.

tain the chromosomal complement of both parental cells. Therefore, it becomes a simple matter to determine dominance and recessiveness of allelic genes. By this means it was demonstrated that 17 different auxotrophic mutants which had been pro- 
duced in this laboratory are recessive with respect to the wildtype (Table 1). The second determination which becomes possible is the identification of different complementation groups among mutants which display the same phenotype $(15,16,17)$. For example, a group of 37 mutants all requiring adenine were hybridized with each other, two at a time. The hybrids so produced were examined to see whether they had retained or lost the requirement for adenine. Those hybrids which retained the adenine requirement obviously came from parental cells which were defective in the same gene and so belong to the same complementation group. However, any two mutants which, on hybridization produce a new cell which no longer requires adenine, complement each other's deficiency and so must be defective in different genes required for the biosynthesis of adenine. Eight different complementation classes have so far been defined among the adenine-requiring mutants (18). Hence, at least eight different genes exist, in any of which mutation can prevent adenine biosynthesis in quantities sufficient to permit cell growth.

Similarly, four different complementation groups have been so far identified among the glycine-requiring mutants. The biochemical block corresponding to each of these different complementation groups is currently under study. For example, it has been demonstrated that the gly $A$ complementation group is deficient in the enzyme serine hydroxymethylase which converts serine to glycine. Similarly, the adenine B complementation group is deficient in the enzyme which converts Nformylglycine amide ribonucleotide into $\mathrm{N}$-formylglycine amidine ribonucleotide.

\section{GENE LOCALIZATION}

When cells from different species are hybridized, chromosome loss occurs, preferentially from one or the other parental cell. This phenomenon, first demonstrated by WEISS and GREEN (19), has been utilized by a variety of investigators for chromosomal localization of the human genes. The process may be illustrated with the chinese hamster auxotroph. If a glycinerequiring Chinese hamster cell is fused with a human cell and the hybrid grown in medium lacking glycine, human chromosomes are rapidly lost. However, chromosomal retention of the gene necessary for glycine biosynthesis is necessary if the hybrid is to continue growing in a glycine-free medium. Identification of the human chromosome which is uniquely retained in all prototrophic hybrids serves to identify the chromosome in which the corresponding human gene is carried. Thus, it has been shown that complementing action for a gly $A$ genetic deficiency is obtained if human chromosome number is retained in a hybrid (20). Similarly, the human gene complementing the proline deficiency is contained on human chromosome number 10. One of the great triumphs of somatic cell genetics has been an assignment of human genes to their autosomal chromosomal locations. As of this time, approximately 30 such marker genes have been localized as a result of work going on in different laboratories. A typical study using mouse-human somatic cell hybrids 
is described in reference 21 .

Studies of this kind have also helped to locate control genes. Several different examples have by now been described by various laboratories. We have shown that when an ade $B$ mutant of the Chinese hamster ovary was fused with a human cell and the resulting hybrid cultivated in medium lacking adenine, all of the human chromosomes were lost except one. This retained human chromosome appears to be number 4 or 5 , and it confers on the hybrid the ability to grow without added adenine. When the resulting hybrid was analyzed for the presence of new isozymes, esterase activity was found of a kind which existed in neither of the parental cells. Further examinations revealed that the new esterase activity appeared to be of Chinese hamster cell origin. Hence it was provisionally concluded that the introduction of human chromosome number 4 (or possibly 5) into the standard Chinese hamster ovary cell stimulates a previously silent gene activity with the result that the new esterase action appears. This method might be capable of generalization. Thus, whenever a new protein synthesis can be demonstrated in a hybrid cell which is present in neither parental cell, at least presumptive evidence exists for the operation regulatory genetic mechanisms (22).

\section{INTERSPECIFIC HYBRIDIZATION}

Somatic cell genetics has made possible other new kinds of genetic operations. One of the most important barriers in classical genetics lay in the fact that mating experiments with consequent genetic analysis was possible only between organisms of the same species. However, it is now possible to produce stable hybrid cell lines from different species, and carry out many kinds of genetic biochemical analyses on the resulting clonal populations. Indeed, Dr. Kao in our laboratory has been able to produce stable hybrids between Chinese hamster cells and those of the chick, and use such hybrids to localize particular genes on chick chromosomes (23).

The exciting prospect, therefore, is now opened up of combining within a single cell, genetic characteristics taken from remote regions of the animal kingdom. This should produce a great flowering of the powers of genetics as a science.

\section{DIFFERENTIATION}

Still another kind of hybridization can be carried out, involving study of differentiation processes. It is not easy to study such processes in simple cell cultures because usually normal differentiated cells do not multiply for more than a small number of generations. Therefore, it is generally not possible to use the methods of somatic cell genetics to explore directly the molecular biology of differentiation genes. However, by hybridization of differentiated cells with tissue culture cells and growth of the resulting hybrids in appropriate selective media, it becomes possible to obtain stable hybrids which retain specific differentiation characteristics. 
For example, we have produced hybrid clones from the fusion of the gly $A$ Chinese hamster auxotrophs with Chinese hamster brain cells and have obtained stable cultures which put out dendritelike processes when cyclic AMP is added to the medium in close analogy to cells from nervous tissue. Approaches of this kind which are going on in several laboratories offer the exciting possibility of making possible genetic biochemical analysis of specific differentiation processes in multiplying cells.

\section{APPLICATION OF CELL GENETICS}

These developments also make possible new approaches to qualitative and quantitative study of the mutagenesis problem. Such studies are useful in order to understand the nature of different kinds of gene action that occur in mammalian cells, the different possibilities of gene regulation, the different kinds of mutations which can be produced, the relationship between mutagenesis and carcinogenesis, and the ability to measure mutagenic action of food additives, drugs and environmental pollutants. It becomes possible to measure quantitatively, or semi-quantitatively, forward mutagenesis by physical, chemical and biological agents by use of the BUdR-visible light technique for isolation of auxotrophic mutants. Reversion in such mutants can be measured directly. By comparing the action of different kinds of mutagens on specific reversion processes, it is often possible to determine whether a given forward mutation was a frame-shift or a base change mutation. By extension of these studies it has become possible to identify and determine the chromosome assignment of human genes associated with particular cell surface antigens $(24,25)$.

These methods make possible a variety of studies on the action of hormones and agents like cyclic adenosine $3^{\prime}: 5^{\prime}$ monophosphate (cyclic AMP). For example, it has been shown that addition of cyclic AMP in the form of a suitable non-hydrolyzable derivative to the medium in which transformed cells are growing causes them to lose morphological and biochemical properties which are characteristic of tumorigenically transformed cells growing in vitro. Concomitant with these changes is an alteration in the microtubular structure inside of the cell. The microtubules change from a sparse, random set of structures to a highly organized parallel array which traverses the entire cell (26). The data appear to justify the hypothesis that some kind of cancer may involve a defect in the microtubular organization which can be brought about by deficiency in cyclic AMP levels. It may also be postulated that the microtubular system functions in the selective exposure of particular chromosomal regions so that different gene sets can become susceptible to activation. Mutagenesis of cell cultures has produced variants with altered responses to cyclic AMP derivatives which may make possible genetic biochemical studies of these effects.

This discussion reveals some of the ways in which the methods of somatic cell genetics appear to afford new pathways for the study of mammalian genetics and biology. The impact of such studies may be expected to produce exciting new developments in medicine. 


\section{LITERATURE CITED}

1a) Puck, Theodore T. and Philip I. Marcus. A Rapid Method for Viable Cell Titration and Clone Production with HeLa Cells in Tissue Culture. (The Use of X-irradiated Cells to Supply Conditioning Factors.) Proc. Nat. Acad. Sci. USA $41: 432$.

1b) Puck, Theodore T., Philip I. Marcus and Steven J. Cieciura. Clonal Growth of Mammalian Cells in vitro. Growth Characteristics of Colonies from Single HeLa Cells with and without a "Feeder" Layer. J. Exp. Med. 103:273.

1c) Puck, Theodore T. 1957. The Genetics of Somatic Mammalian Cells. Advances in Biological and Medical Physics 5:75.

2. Ham, Richard G. and Theodore T. Puck 1962. A Regulated Incubator Controlling $\mathrm{CO}_{2}$ Concentration, Humidity, and Temperature, for Use in Animal Cell Culture. Proc. Soc. Exp. Biol. and Med. 111:67-71.

3. Eagle, H. 1960. Metabolic Studies with Normal and Malignant Human Cells in Culture. The Harvey Lectures 195859 , p. 156 .

4. Ham, Richard G. 1962. Clonal Growth of Diploid Chinese Hamster Cells in a Synthetic Medium Supplemented with Purified Protein Fractions. Exp. Cell Research 28:489.

5. Puck, Theodore T., Steven J. Cieciura and Arthur Robinson. 11 1958. Genetics of Somatic Mammalian Cells III. Long-term Cultivation of Euploid Cells from Human and Animal Subjects. J. Exp. Med. 108:945-956.

6. Puck, Theodore T. and Harold W. Fisher. 1956. Genetics of Somatic Mammalian Cells I. Demonstration of the Existence of Mutants with Different Growth Requirements in a Human Cancer Cell Strain (HeLa). J. Exp. Med. 104:427.

7. Tjio, Joe-Hin and Theodore T. Puck. 1958. The Somatic Chromosomes of Man. Proc. Nat. Acad. Sci. USA 44:1229-1237.

8. Robinson, Arthur, et al. 1960. A Proposed Standard System of Nomenclature of Human Mitotic Chromosomes. J. Am. Med. Assoc. 174:159.

9. Lejeune, J., M. Gautier and R. Turpin. 1959. Etudes des Chromosomes Somatiques de Neuf Enfants Monogoliens. Compt. Rend. Acad. Sci. Paris D. 284:1721.

10. Casperson T., L. Zech, C. Johansson, and S. J. Modest 1970. Identification of Chromosomes by DNA-binding Fluorescent Agents, Chromosoma 30:215.

11. Puck, Theodore T. and Fa-Ten Kao. 1967. Genetics of Somatic Mammalian Cells V. Treatment with 5-Bromodeoxyuri- 
dine and Visible Light for Isolation of Nutritionally Deficient Mutants. Proc. Nat. Acad. Sci. USA 58:1227.

12. Kao, Fa-Ten and Theodore T. Puck. 1968. Genetics of Somatic Mammalian Cells VII. Induction and Isolation of $\mathrm{Nu}-$ tritional Mutants in Chinese Hamster Cells. Proc. Nat. Acad. Sci. USA 60:1275.

13. Kao, Fa-Ten and Theodore T. Puck. 1969. Mammalian Cell Genetics IX: Quantitation of Mutagenesis by Physical and Chemical Agents. J. Cell Phys. 74:245.

14. Harris, Henry 1970. Cell Fusion. Harvard Univ. Press, Cambridge, Mass.; Ephrussi, Boris. 1972. Hybridization of Somatic Cells. Princeton Univ. Press, Princeton, N. J.

15. Kao, Fa-Ten, Robert T. Johnson and Theodore T. Puck. 1969. Genetics of Somatic Mammalian Cells VIII: Complementation Analysis on Virus-fused Chinese Hamster Cells with Nutritional Markers. Science 164:312.

16. Kao, Fa-Ten, Lawrence Chasin and Theodore T. Puck. 1969. Genetics of Somatic Mammalian Cells X. Complementation Analysis of Glycine-requiring Mutants. Proc. Nat. Acad. Sci. USA 64:1284.

17. Kao, Fa-Ten and Theodore T. Puck. 1972. Genetics of Somatic Mammalian Cells XIV: Genetic Analysis in vitro of Auxotrophic Mutants. J. Cell Physiology 80:41.

18. Patterson, David, Theodore T. Puck and Fa-Ten Kao. 1974. Genetics of Somatic Mammalian Cells: Biochemical Genetics of Chinese Hamster Cell Mutants with Deviant Purine Metabolism. Proc. Nat. Acad. Sci. USA 71:2057.

19. Weiss, M. C. and H. Green. 1967. Human-Mouse Hybrid Cell Lines Containing Partial Complements of Human Chromosomes and Functioning Human Genes. Proc. Nat. Acad. Sci. USA 58:1104.

20. Jones, Carol, Paul Wuthier, Fa-Ten Kao and Theodore T. Puck. 1972. Genetics of Somatic Mammalian Cells XV: Evidence for Linkage Between Human Genes for Lactic Dehydrogenase B and Serine Hydroxymethylase. J. Cell Physiology 80:291.

21. Creagen, R. P. et al. 1974. Chromosome Assignments of Genes in Man Using Mouse-human Somatic Cell Hybrids: Cytoplasmic Isocitrate Dehydrogenase and Malate Dehydrogenase to Chromosome 2. Am. J. Human Gen. 26:604.

22. Kao, Fa-Ten and Theodore T. Puck. 1972. Genetics of Somatic Mammalian Cells: Demonstration of a Human Esterase Activator Gene Linked to the Ade B Gene (XVI in the series). Proc. Nat. Acad. Sci. USA 69:3273.

23. Kao, Fa-Ten. 1973. Identification of Chick Chromosomes 
in Cell Hybrids Formed Between Chick Erythrocytes and Chinese Hamster Adenine-requiring Mutants. Proc. Nat. Acad. Sci. USA $70: 2893$.

24. Puck, Theodore T., Paul Wuthier, Carol Jones and Fa-Ten Kao. 1971. Genetics of Somatic Mammalian Cells XIII: Lethal Antigens as Genetic Markers for Study of Human Linkage Groups. Proc. Nat. Acad. Sci. USA 68:3102.

25. Wuthier, Paul, Carol Jones and Theodore T. Puck. 1973. Surface Antigens of Mammalian Cells as Genetic Markers II. J. Exp. Med. 138:229.

26a) Hsie, Abraham W. and Theodore T. Puck. 1971. Mammalian Cell Transformation in Vitro. I. A Morphological Transformation of Chinese Hamster Cells Produced by Dibutyryl Cyclic Adenosine Monophosphate and Testosterone. Proc. Nat. Acad. Sci. USA $68: 358$.

b) Hsie, Abraham W., Carol Jones, and Theodore T. Puck. 1971. Mammalian Cell Transformations in Vitro. II. Further Changes in Differentiation State Accompanying the Conversion of Chines Hamster Cells to Fibroblastic Form by Dibutyryl Adenosine Cyclic 3':5'-Monophosphate and Testosterone. Proc. Nat. Acad. Sci. USA $68: 1648$.

c) Puck, Theodore T., Charles A. Waldren, and Abraham W. Hsie. 1972. Membrane Dynamics in the Action of Dibutyryl Adenosine Cyclic 3':5'-Monophosphate and Testosterone on Mammalian Cells Proc. Nat. Acad. Sci. USA, 69:1943.

d) Porter, Keith R., T. T. Puck, A. W. Hsie, and Donna Kelley, 1974. An Electron Microscope Study of the Effects of Dibutyry Cyclic AMP on Chinese Hamster Ovary Cells. Cell 2 : 145.

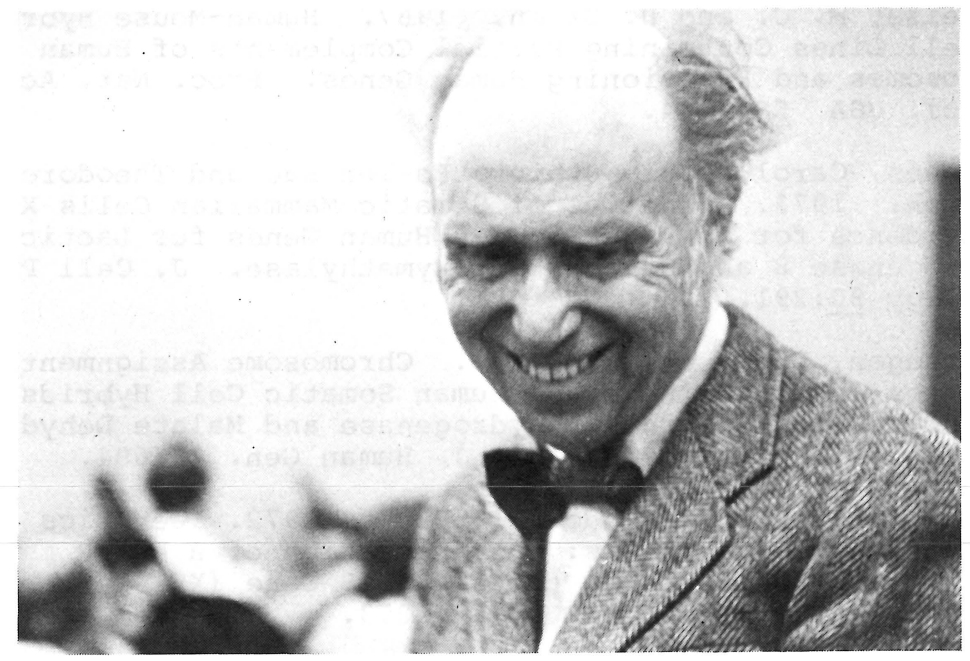

Dr. Theodore T. Puck 